REPORTS OF MORPHOLOGY
Official Journal of the Scientific Society of Anatomists,
Histologists, Embryologists and Topographic Anatomists
of Ukraine

\title{
Organometric parameters of the remaining kidney after removal of the contralateral in immature rats
}

\section{Monastyrskyi V.M.}

National Pirogov Memorial Medical University, Vinnytsya, Ukraine

\section{ARTICLE INFO}

Received: 5 October, 2018

Accepted: 6 November, 2018

UDC: 611.611:611.061:611.068:616.61089.87

\section{CORRESPONDING AUTHOR}

e-mail: vova.monastirskiy@gmail.com Monastyrskyi V.M.

\begin{abstract}
The processes of compensatory hypertrophy of the kidney to the period of puberty are insufficiently studied. Changes in renal parameters after contralateral removal are of scientific interest. The purpose of the study was to establish and compare changes in organometric parameters of the kidney that remained after nephrectomy in non-sexually adult male rats and in sexually mature male rats. Experimental study was performed on 84 non-adult white male rats weighing 53-71 grams, which were kept on a standard vivarium diet. All animals were divided into two groups (42 in each): the first - control, the second - the experimental group. In the control group, the abdominal cavity was opened under ketamine anesthesia, after which the abdominal wall was sutured in layers. All animals of the experimental group performed removal of the left kidney. Animals were withdrawn from the trial by intra-pleural administration of thiopentalsodium $50 \mathrm{mg} / \mathrm{kg}$ after 7, 14, 21, 30, 90 days after nephrectomy. Macroscopic evaluation and description of the kidneys of animals was performed after their removal. The statistical analysis of the obtained results was carried out using the "STATISTICA 5.5" program, using parametric and non-parametric methods for evaluating the obtained results. It was found that in the immature rats, the weight of animals in the experimental group (after nephrectomy) was statistically significantly lower in all terms of the observation compared to the control group, and the weight of the kidney of animals in the experimental group, on the contrary, was statistically significantly higher in all terms of observation. The length, width, thickness, volume of kidneys of animals of the experimental group, as well as the magnitude of increment of these parameters with each term of observation are determined. The greatest increase in organometric parameters of the kidney was observed after 30 days of the postoperative period $(p<0.05)$. Subsequently, on the 60th and 90th day, the magnitude of the increase in organometric parameters of the kidney significantly decreased. The index of hypertrophy of the kidney remained unpaired by nephrectomy, which varied from $52.24 \%$ to $63.21 \%$. The highest rates of hypertrophy were observed between the 21st and 30th days.

Keywords: kidney, nephrectomy, organometry, immature rats.
\end{abstract}

\section{Introduction}

The remaining kidney after nephrectomy cannot be considered an absolutely healthy organ [25]. This is evidenced by various pathological processes that develop in it over time [5]. Studies have shown that to ensure the release of nitrogen metabolism products and the balance of the internal environment of the body, the remaining kidney works at the limit of its capabilities [8].

The remaining functioning kidney, since childhood, has compensatory hyperfiltration, which leads to kidney damage for the period of adolescence in more than $50 \%$ of patients [23]. Experimental studies have shown that male animals show a higher degree of hyperfiltration [6], elevated blood pressure [14], and higher glomerular pressure and hypertrophy of renal corpses.

The controversial statement of clinicians that the growing child's body is characterized by expressed compensatory mechanisms that are not always kept in adults [21]. Several epidemiological clinical studies have shown that one kidney birth increases the risk of developing hypertension, proteinuria and renal failure in childhood [27] and in adulthood [26]. Recent studies have shown that kidney donors are at increased risk (up to 8 times) for renal failure [16]. 
Many authors emphasize that the younger organism has more intensive and more advanced processes of hypertrophy [3]. The majority of patients who have been admitted to nephrectomy in the short term become disabled in connection with the development of chronic renal failure and nephrogenic hypertension, whereas in children, including when they become adults, the percentage of disability is minimal [1, 2]. However, the functional state of a single kidney in children is often significantly disturbed, and chronic renal failure can occur already in childhood or adolescence [13]. In the kidney, left after nephrectomy in children, established with the help of renosonography, the unevenness of proliferative and fibrotic-sclerotic processes, the presence of dysmetabolic disorders, prolonged violations of the natural passage of urine [15]. With age, glomerular hyperfiltration may worsen existing glomerulosclerosis and lead to renal insufficiency [22].

Compensatory mechanisms that underlie hypertrophy of the kidneys are not yet fully understood, mechanisms that provide stabilization of compensatory and adaptive processes are not sufficiently disclosed. Insufficiently studied issues on the preservation of compensatory and restorative mechanisms in the age aspect.

The aim of the study - to establish changes in organometric parameters of the kidney that remained after nephrectomy in immature male rats.

\section{Materials and methods}

An experimental study was performed on 84 immature white male rats weighing 53-71 grams, which were kept on a standard diet in vivarium of the National Pirogov Memorial Medical University, Vinnytsya, Ukraine.

According to the literature, experiments conducted on rats have shown that these animals can be used as a model for studying the course of recovery of the body after nephrectomy and resection of the kidney and the selection of corrective therapy, aimed at the earliest adaptation of the organism to existence in the new conditions [10,11]. Male rats were more sensitive and less adapted to renal excretion [24].

Animal retention and manipulation were conducted in accordance with the "General Ethical Principles of Animal Experiments" adopted by the First National Congress on Bioethics (Kyiv, 2001), and also guided by the recommendations of the "European Convention for the Protection of Vertebrate Animals used for Experimental and Other Scientific Purposes" (Strasbourg, 1985) and the provisions of the "Rules for Preclinical Safety Assessment of Pharmacological Products (GLP)".

All animals were divided into two groups (42 in each): the first - control, the second - the experimental group.

In the control group, the abdominal cavity was opened under ketamine anesthesia, after which the abdominal wall was sutured in layers.

All animals of the experimental group performed surgical intervention - nephrectomy of the left kidney. Rats under general intra-muscle anesthesia (aminazine $10 \mathrm{mg} / \mathrm{kg}$ and ketamine $20 \mathrm{mg} / \mathrm{kg}$ ) were given left-sided nephrectomy by crossing the renal leg between two ligatures and then removing the organ. The operation was carried out as follows. The animal was inserted and fixed with soft straps for the limbs in the position on the back to the operating table. With pararectal incision in the length up to $3-5 \mathrm{~cm}$, layer open the abdominal cavity. The small intestine with a gauze napkin was pulled down and medially. The livers of the kidney and its vessels were isolated from the surrounding tissues. The kidney was molded into the wound and isolated from the fatty tissue of the upper third of the ureter. A clamping device was applied to the ureter, under which they were tied with a catgut lighthouse and then crossed under a clamp. In a droop way, they isolated the renal artery and vein and imposed two clips, between which they were crossed. The kidney was removed, and the stump of the blood vessels were catgut ligatures. The layer of the wound was tightly sewn. Isolated by blunt renal artery and vein and imposed two terminals between which they crossed. The kidney was removed and the stump of blood vessels catgut tied ligatures. The layer of the wound was tightly sewn.

Animals were withdrawn from the trial by intra-pleural administration of thiopental-sodium $50 \mathrm{mg} / \mathrm{kg}$ after $7,14,21$, 30,90 days after nephrectomy. Macroscopic evaluation and description of the kidneys of animals was performed after their removal. Their mass was determined on the laboratory scale of HLR-200 to $0.1 \mathrm{mg}$, and the length, width and thickness of the organ were measured with the help of a caliper to an accuracy of $0.05 \mathrm{~mm}$. The volume of the kidney was calculated according to the formula: $\mathbf{V}=\mathbf{0 , 5 2 3} \times \mathbf{a} \times \mathbf{b} \times \mathbf{c}$, where $\mathbf{a}$ - is length, $b$ - is width, $c$ - is the thickness of the kidney.

The kidney mass index was calculated by obtaining a percentage correlation between the weight of the kidney and the weight of the body of the rat being examined. In the case of animals of the second group, the index of kidney hypertrophy was calculated. It was calculated by obtaining a percentage correlation between the mass of the single kidney and the weight of the two kidneys of the rats of the first control group at this time of the study.

The statistical analysis of the obtained results was carried out using the "STATISTICA 5.5" program, using parametric and non-parametric methods for evaluating the obtained results.

\section{Results}

The results of measuring the organometric parameters of the kidneys in the immature rats of the 1st group were as follows: with increasing body weight during the observation period, the organometric parameters of the kidneys were also increased. So the mass of the right kidney from the first to the 90th day of the observation period increased by 2.05 times (Table 1). The mass of the left kidney, in comparison with the right, on all terms of observation was slightly lower $(p>0.05)$. At the same time, the index of kidney mass decreased by 1.22 times from the first to the 90th day of the observation period, indicating a predominance of growth 
Table 1. Weight of the body and the right kidney of the immature rats of the control and experimental groups.

\begin{tabular}{|c|c|c|c|c|c|c|}
\hline \multirow{2}{*}{$\begin{array}{c}\text { The term of the } \\
\text { postoperative } \\
\text { period }\end{array}$} & \multicolumn{3}{|c|}{ Control group $(\mathrm{n}=42)$} & \multicolumn{3}{c|}{ Experimental groups $(\mathrm{n}=42)$} \\
\cline { 2 - 7 } & Animal weight $(\mathrm{g})$ & $\begin{array}{c}\text { Weight of the } \\
\text { kidney }(\mathrm{g})\end{array}$ & $\begin{array}{c}\text { Kidney Weight } \\
\text { Index }(\%)\end{array}$ & Animal weight $(\mathrm{g})$ & Kidney weight $(\mathrm{g})$ & $\begin{array}{c}\text { Kidney Weight } \\
\text { Index }(\%)\end{array}$ \\
\hline 1 day & $61.33 \pm 4.03$ & $0.372 \pm 0.012$ & $0.603 \pm 0.022$ & $62.55 \pm 4.09$ & & \\
\hline 7 days & $74.78 \pm 2.68^{*}$ & $0.385 \pm 0.015$ & $0.510 \pm 0.007^{*}$ & $68.44 \pm 1.33 \#$ & $0.440 \pm 0.027 \#$ & $0.642 \pm 0.048 \#$ \\
\hline 14 days & $86.07 \pm 2.61^{*}$ & $0.402 \pm 0.012$ & $0.467 \pm 0.004^{*}$ & $80.67 \pm 2.49^{*} \#$ & $0.475 \pm 0.012 \#$ & $0.592 \pm 0.009 \#$ \\
\hline 21 days & $97.35 \pm 2.63^{*}$ & $0.457 \pm 0.010^{*}$ & $0.459 \pm 0.003$ & $91.83 \pm 2.32^{*} \#$ & $0.558 \pm 0.012^{*} \#$ & $0.597 \pm 0.007 \#$ \\
\hline 30 days & $108.6 \pm 2.8^{*}$ & $0.477 \pm 0.007$ & $0.442 \pm 0.006$ & $102.8 \pm 2.4^{*} \#$ & $0.597 \pm 0.010^{*} \#$ & $0.585 \pm 0.007 \#$ \\
\hline 60 days & $122.5 \pm 2.7^{*}$ & $0.540 \pm 0.023^{*}$ & $0.447 \pm 0.010$ & $116.7 \pm 2.5^{*} \#$ & $0.635 \pm 0.015^{*} \#$ & $0.551 \pm 0.009^{*} \#$ \\
\hline 90 days & $153.6 \pm 3.7^{*}$ & $0.760 \pm 0.040^{*}$ & $0.495 \pm 0.015^{*}$ & $132.7 \pm 2.3^{*} \#$ & $0.788 \pm 0.015^{*}$ & $0.587 \pm 0.003^{*} \#$ \\
\hline
\end{tabular}

Note: ${ }^{*}$ - statistically significant differences $(p<0,05)$ according to the Mana-Whitney criterion between the corresponding indicators in comparison with the indicators of the previous term of research. \# Are statistically significant differences $(p<0.05)$ according to the Mana-Whitney criterion between the respective indices compared with the control animals.

rate of body weight of rats over the rate of weight gain of the kidneys. The volume of the right kidney thus increased during the course of observation from $75.24 \pm 4.65 \mathrm{~mm}^{3}$ for the first day to $407.8 \pm 14.3 \mathrm{~mm}^{3}$ for the 90th day. The length of the right kidney has increased from $7.950 \pm 0.150 \mathrm{~mm}$ to $14.40 \pm 0.07 \mathrm{~mm}$, the width - from $4.733 \pm 0.100 \mathrm{~mm}$ to $7.883 \pm 0.089 \mathrm{~mm}$, the thickness - from $3.817 \pm 0.089 \mathrm{~mm}$ to $6.867 \pm 0.156 \mathrm{~mm}$.

In the immature animals of the second (experimental) group at day 7 after nephrectomy, the body weight of rats was less than that of the animals in the same group of animals in the same group at $8.47 \%$, at 14 days - by $6.27 \%$, at 21 days $-5,67 \%$, for 30 days $-5.34 \%$, for 60 days $-4.76 \%$, for 90 days $-13.63 \%$. However, organometric parameters of the right kidney were statistically significantly more control values of animals of the first group at all times, especially on the 30th day of observation. Thus, for the 7th day after nephrectomy, the mass of the right kidney of rats was higher $(p<0.05)$ values in the similar term of animals of the first group by $11.36 \%$, for 14 days - by $16.67 \%$, for 21 days $17.86 \%$, for 30 days $-20 \%$, for 60 days $-15.62 \%$. At 90 days no statistically significant difference was noted.

The index of kidney weight in non-immature animals in

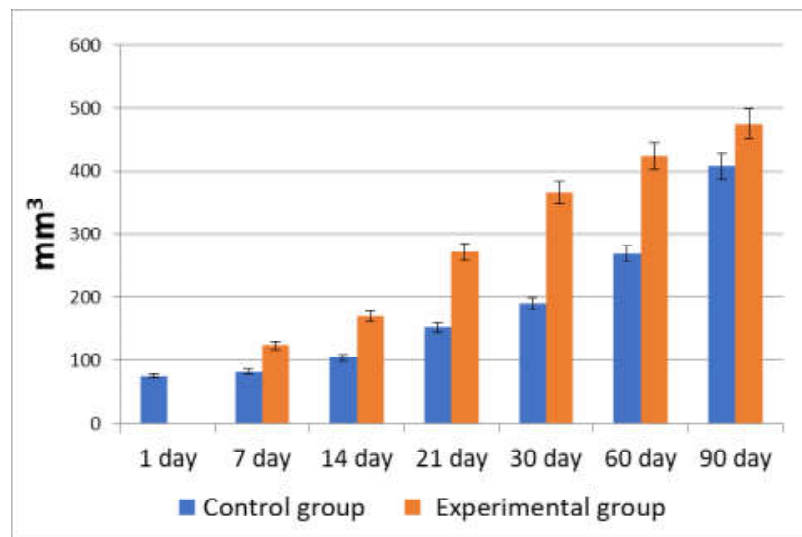

Fig. 1. Volume of the right kidney of immature rats in different terms after the operation of the control and experimental groups. the second (experimental) group was statistically significantly higher throughout the post-operation observation period compared to the similar terms of animals in the first control group.

Parameters of other organometric indices of the right kidney of animals of the second (experimental) group also had significant differences. The length of the right kidney compared with the similar indicator of animals in the first control group was greater after 7 days after nephrectomy by $12.27 \%$, after 14 days - by $15.02 \%$, in 21 days - by $17.49 \%$, after 30 days - by $19.73 \%$, after 60 days - by $15.03 \%$, after 90 days - by $4.00 \%$. The width of the right kidney was greater after 7 days after nephrectomy by $12.50 \%$, after 14 days - by $14.94 \%$, in 21 days - by $17.62 \%, 30$ days later - by $19.62 \%$, after 60 days - by $12.22 \%$, after 90 days - by $6.52 \%$. The thickness of the right kidney was greater after 7 days after nephrectomy by $12.30 \%$, after 14 days - by $15.26 \%$, in 21 days - by $17.53 \%$, after 30 days - by $19.45 \%$, after 60 days by $14.74 \%$, after 90 days - by $4.18 \%$.

The statistically significant decrease in the growth rates of all organometric indices in 90 days draws attention.

It is very important to know how the volume of the kidney has changed, since it is believed that the volume of kidneys is the optimal parameter for prediction of renal function [12]. The volume of the right kidney, after 7 days after nephrectomy, was $32.71 \%$ higher, compared with the same indicator of animals in the first control group (fig. 1). The largest increase in volume was observed after 30 days of postoperative period $(48.05 \%)$. Subsequently, on the 60th and 90th day, the increase in renal volume decreased to $36.38 \%$ and $14.02 \%$ respectively.

It should be noted that the index of hypertrophy of the kidney after the removal of the contralateral ranged from $52.24 \%$ to $63.21 \%$. The highest rates of hypertrophy were observed between the 21 st and 30th days.

\section{Discussion}

The data we obtained are in agreement with the results of other authors [4], when the absolute dry kidney weight 
was increased in rats 7 days after unilateral nephrectomy (hypertrophy of the kidneys), and the mean value was $29.9 \%$ higher than the values removed from the contralateral kidney.

A progressive increase in the weight of kidney of rats was also established after removal of the left kidney, which reached its peak after 30 days [9].

According to research $[28,29]$, renal compensatory hypertrophy restores normal renal function after nephrectomy due to an increase in organ size due to cell growth, and not their proliferation [17].

In the compensatory reaction of the kidney remaining after nephrectomy in immature rats, a significant increase in the indexes of all structural components of the nephron of the cortical substance was established [19]. The highest rate of growth occurs in a seven-day period after the removal of the kidney. Ultrastructure of the cortical substance of the kidneys of unborn animals after the performed nephrectomy is changing already in the early stages of the experiment, when significant reactive changes occur in all components of the nephron. Although the kidney compensatory reaction develops as a reaction to restore normal renal function, in the cortical substance, in addition to hypertrophied, the number of atrophied, diminished kidney cells increases [18]. Enlarged capsules are enlarged and uneven. In the late stages of the experiment, after nephrectomy, the presence of both compensatory and destructive changes in the components of the nephron was established.

The use of flow cytometry with simultaneous histological studies showed that the response of adults and young rats to the removal of one of the kidneys is the same, but in

\section{References}

[1] Abdihalikov, T. Zh. (2016). Functional condition of the single kidney in patients after surgical intervention due to urinary stone disease. Bulletin of KRSU, 16(7), 3-6.

[2] Abdihalikov, T. Zh., Chernetsova, G. S., \& Kolesnichenko, I. V. (2013). Rehabilitation of patients with a single kidney after undergoing nephrectomy. Bulletin of KRSU, 13(11), 3-5.

[3] Alaygut, D., Soylu A., Kasap, B., Turkmen, M., Cakmakci, H., \& Kavukcu, S. (2013). The Relationships Between Renal Compensatory Hypertrophy Etiologic Factors and Anthropometric Development in the Pediatric Age Group. Urology, 82(2), 442-447. doi:10,1016/ j.urology.2013.03.024

[4] Babić, N., Huskić, J., \& Nakać-Išindić, E. (2007) Angiotensin Converting Enzyme Activity in Compensatory Renal Hypertrophy. Bosn. J. Basic Med. Sci., 7(1), 79-83. doi: $10.17305 /$ bjbms.2007.3098

[6] Celebi, Z. K., Peker, A., Kutlay, S., Kocak, S., Tuzuner, A., Erturk, S., Keven, K. \& Sengul, S. (2017) Effect of unilateral nephrectomy on urinary angiotensinogen levels in living kidney donors: 1 year follow-up study. Journal of the ReninAngiotensin Aldosterone System, 18(4), 1-6. Doi: 10.1177/ 1470320317734082

[7] Delgadillo, D., Barbier, O., Sierra, G., \& Reyes, J. L. (2014). Retinoic acid improves recovery after nephrectomy and decreases renal TGFbeta1 expression. Gender-related effects. Fundam Clin Pharmacol., 28, 170-179. doi.org/ $10.1111 / \mathrm{fcp} .12013$

[8] Domínguez-Calderóna, A., Ávila-Floresb, A., Poncea, A., López- immature animals, the growth of cells in the phase $S$ cell cycle after 7-14 days is statistically significantly more than that of the mature [20]. According to recent studies, with loss of renal tissue in the renal epithelial cells MDCK (MadinDarby cells), a protein with a zona occludens 2 (ZO-2) compound causes cellular hypertrophy by two mechanisms: prolonging the time that cells are carried out in the phase G1 cell cycle due to the increase in the cyclone D1 level and increasing the rate of protein synthesis [7].

In the future, it is planned to compare changes in organometric parameters of the kidney, remaining after nephrectomy, in immature and mature animals.

\section{Conclusions}

1. In the immature rats, the weight of animals in the experimental group (after nephrectomy) was statistically significantly lower in all observation periods compared to the control group.

2. The weight of the kidney of the animals of the experimental group, as compared with the control group, was, conversely, statistically significantly higher in all terms of observation.

3. The length, width, thickness and volume of the kidneys of animals in the experimental group were also larger with each observation period $(p<0.05)$.

4. The largest increase in organometric parameters of the kidney was observed after 30 days of postoperative period. Subsequently, on the 60th and 90th day, the magnitude of the increase in organometric parameters of the kidney significantly decreased.

Bayghenc, E., Calderón-Salinasd, J. V., Reyesa, J. L. ... González-Mariscala, L. (2016). ZO-2 silencing induces renal hypertrophy through a cell cycle mechanism and the activation of YAP and the mTOR pathway. Mol. Biol. Sel., 27(10), 15811595. doi: $10.1091 / \mathrm{mbc}$.E15-08-0598

[9] Dvorak, V. S., Boiko, A. I., Shcherbak, O. Iu., \& Sosnin, M. D. (2010). The only kidney: the problem of relapse or disease of nephrolithiasis. Urology, 14(addition), 248-250.

[10] Eladl, M. A., Elsaed, W. M., Atef, H., \& El-Sherbiny, M. (2017). Ultrastructural changes and nestin expression accompanying compensatory renal growth after unilateral nephrectomy in adult rats. Int. J. Nephrol. Renovasc. Dis., 10, 61-76. doi: 10.2147/IJNRD.S121473

[11] Ivanov, A. P., \& Fateev, D. M. (2011). Effect of nephrectomy and kidney resection on catecholamine metabolism in rats. Yaroslavl Pedagogical Bulletin. (Natural Sciences), 3(1), 104108.

[12] Ivanov, A. P., \& Tyuzikov, I. A. (2011). The effect of experimental operational stress (nephrectomy and kidney resection) on mediator-hormonal homeostasis in rats. Modern problems of science and education, 3. Doi: http://www.scienceeducation.ru/ru/article/view?id=4657

[13] Jeon, H. G., Gong, I. H., Hwang, J. H., Choi, D. K., Lee, S. R., \& Park, D. S. (2012). Prognostic significance of preoperative kidney volume for predicting renal function in renal cell carcinoma patients receiving a radical or partial nephrectomy. BJU Int., 109(10), 1468-1473. doi: 10,1111/j.1464- 
410X.2011.10531.x

[14] Kundin, V. Iu. (2014). Complex radionuclide evaluation of structural and functional state of the single kidney in children. Ukrainian Journal of Nephrology and Dialysis, 42(2), 19-24.

[15] Lankadeva, Y. R., Singh, R. R., Tare, M., Moritz, K. M., \& Denton, K. M. (2014). Loss of a kidney during fetal life: long term consequences and lessons learnt. Am. J. Physiol. Renal Physiol., 306, F791-F800. doi.org/10.1152/ajprenal.00666.2013

[16] Makieieva, N. I., \& Pidvalna, N. A. (2015). Ultrasonic characteristics of structural and tissue changes of solitary kidney in children. Pediatrics, 2, 40-42.

[17] Muzaale, A. D., Massie, A. B., Wang, M. C., Montgomery, R. A., McBride, M. A., Wainright, J. L., \& Segev, D. L. (2014). Risk of End-Stage Renal Disease Following Live Kidney Donation. JAMA, 311(6), 579-586. doi:10,1001/jama.2013.285141

[18] Oliveria, C. S., Joshee, L., Zalups, R. K., \& Bridges Ch.C. (2016). Compensatory Renal Hypertrophy and the Handling of an Acute Nephrotoxicant in a Model of Aging. Exp. Gerontol., 75, 16-23. doi: 10.1016/j.exger.2016.01.001

[19] Pivtorak, V. I., \& Monastyrskyi, V. M. (2015). Electron Microscopic Changes Only Kidney, Remaining after the Contralateral Nephrectomy, in Immature Rats. Bulletin of problems in Biology and Medicine, 2(121), 250-254.

[20] Pivtorak, V. I., \& Monastyrskyi, V. M. (2015). Features of Structural Components of the Nephron of Renal Cortex of the Solitary Kidney in Immature Rats. Galician Medicinal Herald, 22(3), 43-46.

[21] Pivtorak, V. I., \& Monastyrskyi, V. M. (2016). Changes cell cycle kidney cells cortex contralateral after nephrectomy in immature rats. Bulletin of problems in Biology and Medicine, 2(129), 253-257.

[22] Pugachev, A. G., Chernetsova, G. S., Usupbaev, A. Ch., \& Moskalev, I. N. (2005). The results of the treatment of obstructive uropathy (in children, adults operated on in children, and in adult patients. Bishkek, 225.

[23] Saxena, A. B., Myers, B. D., Derby, G., Blouch, K. L., Yan, J., Ho, B., \& Tan, J. C. (2006). Adaptive hyperfiltration in the aging kidney after contralateral nephrectomy. Am. J. Physiol. Renal Physiol., 291(3), 629-634. doi:10,1152/ajprenal.00329.2005

[24] Schreuder, M. F. (2018). Life with one kidney. Pediatr Nephrol. 33(4), 595-604. doi: 10.1007/s00467-017-3686-4

[25] Shapiro, J. I., \& Dial, L. D. (2012). How Safe Is Unilateral Nephrectomy? Hypertension, 60(6), 1383-1384. doi:[10.1161/ HYPERTENSIONAHA.112.200550]

[26] Stus, V. P., \& Barannik K. S. (2016). Functional state and compensatory adaptive powers of the paired organ - the kidneys under conditions of one-sided defeat or a single kidney remaining after nephrectomy. Urology, 20(1), 5-16.

[27] Westland, R., Kurvers, R. A. J., van Wijk, J. A. E., \&Schreuder, M. F. (2013). Risk Factors for Renal Injury in Children with a Solitary Functioning Kidney. Pediatrics, 131(2): e478-e485. doi: 10,1542/peds.2012-2088

[28] Westland, R., Schreuder, M. F., Bökenkamp, A., Spreeuwenberg, M. D., \& van Wijk, J. A. E. (2011). Renal injury in children with a solitary functioning kidney - the KIMONO study. Nephrol. Dial. Transplant., 26(5), 1533-1541. doi.org/ 10.1093/ndt/gfq844

[29] Williams, Cl. R., Wynne, B. M., Walker, M., Hoover, R. S., \& Gooch, J. L. (2014). Compensatory renal hypertrophy following uninephrectomy is calcineurin-independent. J. Cell Mol. Med., 18(12), 2361-2366. doi: 10.1111/jcmm.12438

[30] Xu, J., Chen, J., Dong, Z., Meyuhas, O., \& Chen, J.-K. (2015). Phosphorylation of ribosomal protein S6 mediates compensatory renal hypertrophy. Kidney Int., 87(3), 543-556. doi: 10.1038/ki.2014.302

\section{ОРГАНОМЕТРИЧНІ ПАРАМЕТРИ НИРКИ, ЩО ЗАЛИШИЛАСЯ ПІСЛЯ ВИДАЛЕННЯ КОНТРАЛАТЕРАЛЬНОЇ, У СТАТЕВОНЕЗРІЛИХ ЩУРІВ}

\section{Монастирський В.М.}

Процеси компенсаторної гіпертрофрії нирки до періоду статевої зрілості вивчені недостатньо. Зміни параметрів нирки після видалення контралатеральної представляють науковий інтерес. Мета дослідження - встановити зміни органометричних показників нирки, що залишилась після нефректомії, у статевонезрілих щурів-самців. Експериментальне дослідження виконано на 84 статевонезрілих білих щурах-самиях масою 53-71 грамів, котрих утримували на стандартному раціоні віварію. Всіх тварин розподілили на дві групи (по 42 у кожній): перша - контрольна, друга - дослідна група. У контрольній групі під кетаміновим знеболенням розкривали черевну порожнину, після чого пошарово ушивали черевну стінку. Усім тваринам дослідної групи виконували видалення лівої нирки. Тварин виводили з досліду шляхом внутрішньоплеврального введення Тіопенталу натрію 50 мг/ке через 7, 14, 21, 30, 90 діб після нефректомії. Макроскопічну оцінку та описання нирок тварин проводили після їх вилучення. Статистичний аналіз отриманих результатів проведений із застосуванням програми "STATISTICA 5.5" з використанням параметричних і непараметричних методів оцінки отриманих результатів. Встановлено, що у статевонезрілих щурів маса тварин дослідної групи (після нефректомії), порівняно з контрольною групою, була статистично значуще меншою, а маса нирки тварин дослідної групи, навпаки, була статистично значуще більщою на всіх термінах спостереження. Визначені довжина, иирина, товщина, об'єм нирки тварин дослідної групи, а також величини приросту цих параметрів у кожний термін експерименту. Таким чином, максимальну величину приросту органометричних показників нирки спостерігали через 30 діб післяопераційного періоду (p<0,05). У подальшому, на 60 та 90 добу експерименту, величина приросту органометричних показників нирки суттєво зменшувалася. Визначено індекс гіпертрофрії нирки, що залишилася після нефрректомії, котрий коливався від 52,24\% до 63,21\%. Найбільші показники гіпертрофрії встановлені між 21 та 30 добою.

Ключові слова: нирка, нефректомія, органометрія, статевонезрілі щури.

\section{ОРГАНОМЕТРИЧЕСКИЕ ПАРАМЕТРЫ ПОЧКИ, ОСТАВШЕЙСЯ ПОСЛЕ УДАЛЕНИЯ КОНТРАЛАТЕРАЛЬНОЙ, У НЕПОЛОВОЗРЕЛЫХ КРЫС \\ Монастырский В.H.}

Процессы компенсаторной гипертрофии почки до периода половой зрелости изучены недостаточно. Изменения параметров почки после удаления контралатеральной представляют научный интерес. Цель исследования - установить изменения органометрических показателей почки, оставщейся после нефрэктомии, у неполовозрелых крыс-самцов. Экспериментальное исследование выполнено на 84 неполовозрелых белых крысах-самцах массой 53-71 граммов, которых 
содержали на стандартном рационе вивария. Всех животных разделили на две группы (по 42 в каждой): первая - контрольная, вторая - опытная группа. В контрольной группе под кетаминовым обезболиванием вскрывали брюшную полость, после чего брюшную стенку послойно ушивали. Всем животным опытной группы выполняли удаление левой почки. Животных выводили из опыта путем внутриплеврального введения Тиопентала натрия 50 мг/кг через 7, 14, 21, 30, 90 суток после нефрэктомии. Макроскопическую оценку и описание почек животных проводили после их удаления. Статистический анализ полученных результатов проведен с применением программы "STATISTICA 5.5" с использованием параметрических и непараметрических методов оценки полученных результатов. Установлено, что у неполовозрелых крыс масса животных опытной группы (после нефрэктомии) по сравнению с контрольной группой, была статистически значимо меньше, а масса почки животных опытной группы, наоборот, была статистически значимо больще на всех сроках наблюдения. Определены длина, ширина, толщина, объем почки животных опытной группы, а также величины прироста этих параметров в каждый срок эксперимента. Таким образом, максимальную величину прироста органометрических показателей почки наблюдали через 30 суток послеоперационного периода $(p<0,05)$. В дальнейшем, на 60 и 90 сутки эксперимента величина прироста органометрических показателей почки существенно уменьшалась. Определен индекс гипертрофии почки, оставшейся после нефрэктомии контралатеральной, который колебался от 52,24\% до 63,21\%. Наибольшие показатели гипертрофии установлены между 21 и 30 сутками.

Ключевые слова: почка, нефрэктомия, органометрия, неполовозрелые крысы. 